\title{
PENERAPAN MODEL PEMBELAJARAN DISCOVERY LEARNING DALAM MENINGKATKAN HASIL BELAJAR EKONOMI SISWA KELAS XII IPA 2 SMA NEGERI 8 PEKANBARU TP. 2016 / 2017
}

(Application of Discovery Learning Learning Model in Improving Economic Learning Results Class XII IPA Student 2 SMA N 8 Pekanbaru Academc Year 2016/2017

\author{
Oleh: Darmina $\left.{ }^{*}\right)$ \\ HP:08127635921 \\ email: darmina_ku@yahoo.co.id
}

*) Guru SMA Negeri 5 Pekanbaru

\begin{abstract}
This research is motivated by a lack of students 'ability to master the concepts in Economics subjects, this is indicated by many students who score below the determined KKM, namely 76. The students' ability to master the concept is low because the ongoing learning process is teacher-centered where learning is only emphasize students to memorize material only, so as not to provide opportunities for students to construct their own knowledge through their learning experiences. This study tries to apply the discovery learning model. The purpose of this study is to improve student learning outcomes through the application of Discovery Learning Learning models in Economic subjects in class XII IPA-2 Pekanbaru 8 High School. The method used in this study is the class action research method (CAR). Where in this study there are three variables, namely input variables, process variables, and output variables. The research procedure consists of the planning stage, the implementation phase of the action, the observation and evaluation stage, and the analysis and reflection stages. Data collection techniques in this study were taken by using student activity observation sheets and teacher activity observation sheets, as well as evaluating the material taught in each cycle. The subjects in this study were students of class XII IPA-2 Pekanbaru 8 High School, amounting to 35 people and this study was devoted to Economics subjects. Based on the results of this study indicate that the improvement of the learning process and student learning activities that have an impact on student learning outcomes can be shown in the first cycle of student learning outcomes, from the results of analysis used, students who complete the economic learning process in Kejra Paper and Adjustment Journal material, from 35 students were subjected to action, 26 students completed learning with a percentage of $74.28 \%$ and students who received an unfavorable category were 9 students with a percentage of $25.71 \%$, of the 9 students 6 students who were in the very good category 17,14\%, whereas in cycle II where 35 students were subjected to action, 34 of them were in very good category, had reached completeness namely 97.14\% while those that were still not completed were only 1 student, which was 2.86\%. Thus the hypothesis that reads If applied to the Learning Learning Model Learning in Economic subjects in class XII IPA-2 Pekanbaru 8 High School, will increase and be accepted.
\end{abstract}

Keywords: Learning Outcomes, Discovery Learning Learning Models in Economics subjects 


\section{PENDAHULUAN}

Perkembangan dan kemajuan suatu bangsa sangat di pengaruhi oleh mutu pendidikan, karena pendidikan merupakan sarana yang sangat penting untuk pembinaan, pendidikan juga merupakan usaha sadar untuk menyiapkan para peserta didik melalui bimbingan, pengajaran, dan latihan bagi peranannya di masa yang akan datang. Pendidikan dapat berlangsung pada masyrakat, keluarga dan sekolah. Minat belajar adalah kecenderungan seseorang untuk merasa tertarik pada suatu objek dan berusaha untuk menekuninya.

Undang-undang Sistem Pendidikan Nasional nomor 20 tahun 2003 menyatakan bahwa pembelajaran adalah proses interaksi peserta didik dengan pendidik dan sumber belajar pada suatu lingkungan belajar. Definisi pendidikan sangat beragam, Al-Ghazali dalam Mahmud (2010: 17) mendefenisikan pendidikan sebagai sebuah proses pembiasan (riyadhah). Pembiasan yang dimaksud oleh Al-Ghazali adalah upaya menimbulkan respon pada siswa melalui pembimbingan secara emosi dan fisik.

Salah satu metode pembelajaran yang dapat digunakan adalah pembelajaran discovery learning. Model pembelajaran discovery learning merupakan suatu model pembelajaran yang mengutamakan diskusi, problem solving, metode simulasi, bekerja kelompok dan metode lain yang menunjang berkembangnya hubungan sosial siswa, siswa akan mandiri, dapat membantu menyelesaikan masalah, terjadinya pertukaran informasi, dan transfer pengetahuan.

\section{Hakekat Pembelajaran}

Pembelajaran adalah proses interaksi peserta didik dengan pendidik dan sumber belajar pada suatu lingkungan belajar. Pembelajaran merupakan bantuan yang diberikan pendidik agar dapat terjadi proses pemerolehan ilmu dan pengetahuan, penguasaan kemahiran dan tabiat , serta pembentukan sikap dan kepercayaan pada peserta didik. Dengan kata lain, pembelajaran adalah proses untuk membantu peserta didik agar dapat belajar dengan baik. Proses pembelajaran dialami sepanjang hayat seorang manusia serta dapat berlaku di manapun dan kapanpun. Pembelajaran mempunyai pengertian yang mirip dengan pengajaran, walaupun mempunyai konotasi yang berbeda.

Pembelajaran adalah pemberdayaan potensi peserta didik menjadi kompetensi. Kegiatan pemberdayaan ini tidak dapat berhasil tanpa ada orang yang membantu. Menurut Dimyati dan Mudjiono (Syaiful Sagala, 2011: 62) pembelajaran adalah kegiatan guru secara terprogram dalam desain instruksional, untuk membuat belajar secara aktif, yang menekankan pada penyediaan sumber belajar.

Dalam Undang-Undang No. 20 Tahun 2003 Tentang Sistem Pendidikan Nasional pasal 1 ayat 20 dinyatakan bahwa Pembelajaran adalah Proses interaksi peserta didik dengan pendidik dan sumber belajar pada suatu lingkungan belajar.

Belajar adalah berubah atau bahasa mengubah tingkah laku. Morgan dalam Suprijono (2009: 3) belajar adalah perubahan perilaku yang bersifat permanen sebagai hasil dari pengalaman. Selanjutnya menurut Hamalik (2001: 37) belajar adalah "suatu proses perubahan tingkah laku individu melalui interaksi dengan lingkungan" dan Slameto (2010: 2) mengatakan bahwa belajar adalah suatu proses usaha yang di lakukan seseorang untuk memperoleh suatu perubahan tingkah laku yang baru secara keseluruhan, sebagai hasil pengalamannya sendiri dalam interaksi dengan lingkungannya.

Skinner dalam Dimyati dan Mudjiono (2009: 9) berpandangan bahwa belajar adalah suatu perilaku pada saat orang belajar maka responnya menjadi lebih baik. Sebaliknya, bila ia tidak belajar maka responnya menurun. Sedangkan murut Harold Spears dalam Suprijono (2009: 2) Learning is to observe, to read to iitate, to try something them selves, to listen, to follow direction (dengan kata lain, bahwa belajar adalah mengamati, membaca, meniru, mencoba sesuatu, mendengar, dan mengikuti arah tertentu).

\section{Hasil Belajar}


Menurut Sudjana (2009: 56-57) hasil belajar yang dicapai oleh siswa melalui proses belajar mengajar yang optimal cenderung menunjukan hasil yang berciri sebagai berikut:

a. Kepuasan dan kebanggaan yang dapat menumbuhkan motivasi belajar intrinsik pada diri siswa.

b. Menambah keyakinan akan kemampuan dirinya.

c. Hasil belajar yang dicapai bermakna bagi dirinya seperti akan tahan lama diinginkan, membentuk perilakunya, bermanfaat untuk mempelajari aspek lain, dapat digunakan sebagai alat untuk memperoleh informasi dan pengetahuan lainya, kemauan dan kemampuan untuk belajar sendiri, dan mengembangkan kreativitasnya.

d. Hasil belajar diperoleh siswa secara menyeluruh (komperhensif),

e. Kemampuan siswa untuk mengontrol atau menilai dan mengandalikan dirinya terutama dalam menilai hasil yang dicapai maupun menilai dan mengandalikan proses dan usaha belajarnya.

Menurut Hamalik (2001: 159) hasil belajar adalah menunjukan pada prestasi belajar, sedangkan prestasi belajar merupakan indikator adanya derajat perubahan tingkah laku siswa. Hasil belajar merupakan hasil dari suatu interaksi hasil belajar dan tindak mengajar. Dari sisi guru, tindak mengajar diakhiri dengan proses evaluasi hasil belajar. Dari sisi siswa, hasil belajar merupakan puncak proses belajar yang merupakan bukti dari usaha yang telah dilakukan. Menurut Hamalik (2001: 155) hasil belajar tampak sebagai terjadinya perubahan tingkah laku pada diri siswa, yang dapat diamati dan diukur dalam perubahan pengetahuan, sikap, dan ketrampilan.

Perubahan dapat diartikan terjadinya peningkatan dan pengembangan yang lebih baik dibandingkan dengan sebelumnya, misalnya dari tidak tahu menjadi tahu, sikap tidak sopan menjadi sopan dan sebagainya. Menurut Arifin (2009: 47) hasil belajar merupakan indikator dari perubahan yang terjadi pada individu setelah mengalami proses belajar mengajar, dimana untuk mengungkapkannya menggunakan suatu alat penilaian yang disusun oleh guru, seperti tes evaluasi.

Sutrisno, (2008: 1) menyatakan bahwa hasil belajar merupakan kemampuan belajar yang ditunjukkan dalam penampilan yang tetap sebagai akibat dari proses belajar yang terjadi melalui program yang menyediakan fakta-fakta, bukti-bukti, keterangan dan sebagainya. Selanjutnya Nasrun (2002: 21) dalam secara umum hasil belajar dapat diartikan sebagai suatu hasil pekerjaan yang telah dicapai dengan usaha atau diperoleh dengan jalan keuletan bekerja yang dapat diukur dengan alat ukur yang disebut dengan tes. Menurut Sudjana (2009: 3) hasil belajar adalah mencerminkan tujuan pada tingkat tertentu yang berhasil dicapai oleh anak didik (siswa) yang dinyatakan dengan angka atau huruf. Hasil belajar yang dimaksudkan tidak lain adalah nilai kemampuan siswa setelah evaluasi diberikan sebagai perwujudan dari upaya yang telah dilakukan selama proses belajar mengajar berlangsung.

Hasil belajar adalah pola-pola perbuatan, nilai-nilai, pengertian-pengertian, sikap-sikap, apresiasi dan keterampilan. Merujuk pemikiran Gagne dalam Suprijono (2009: 5) menyebutkan bahwa perubahan perilaku yang merupakan hasil belajar berupa: Informasi verbal, Kecakapan intelektual, Sterategi kognitif, Kecakapan motorik, Sikap

Sutrisno (2008: 25) mengemukakan "hasil" belajar merupakangambaran tingkat penguasaan siswa terhadap sasaran belajar pada topik bahasan yang dieksperimenkan, yang diukur dengan berdasarkan jumlah skor jawaban benar pada soal yang disusun sesuai dengan sasaran belajar. Suyono (2009: 8) menyatakan hasil belajar dapat dijelaskan dengan memahami dua kata yang membentuknya, yaitu "hasil" dan "belajar". Pengertian hasil menunjuk kepada suatu perolehan akibat dilakukannya suatu aktivitas yang mengakibatnya berubahnya input secara fungsional.

Faktor-Faktor yang Mempengaruhi Hasil Belajar Siswa 
Selanjutnya Slameto, (2010: 64) menyatakan bahwa faktor-faktor yang dimaksud dalam hasil belajar itu dapat dibagi menjadi 2 bagian besar yaitu faktor internal dan faktor eksternal yaitu Faktor internal yang terdiri dari: faktor biologis dan . faktor psikologis, sedangkan faktor eksternal yang terdiri dari: lingkungan keluarga, lingkungan sekolah, lingkungan masyarakat

\section{Model Pembelajaran Discovery Learning}

Model pembelajaran discovery adalah model mengajar yang mengatur pengajaran sedemikian rupa sehingga anak didik memperoleh pengetahuan yang sebelumnya belum diketahuinya itu tidak melalui pemberitahuan, sebagian atau seluruhnya ditemukan sendiri.

Model pembelajaran discovery learning diartikan sebagai prosedur mengajar yang mementingkan pengajaran perseorangan, memanipulasi objek sebelum sampai pada generalisasi. Sedangkan Bruner menyatakan bahwa anak harus berperan aktif di dalam belajar. Lebih lanjut dinyatakan, aktivitas itu perlu dilaksanakan melalui suatu cara yang disebut discovery learning. Discovery yang dilaksanakan siswa dalam proses belajarnya, diarahkan untuk menemukan suatu konsep atau prinsip.

Metode pembelajaran discovery learning merupakan suatu metode pengajaran yang menitip beratkan pada ketanggapan siswa dalam belajar. Dalam proses pembelajaran dengan metode ini, guru hanya bertindak sebagai pembimbing dan fasilitator yang mengarahkan siswa untuk menemukan konsep, dalil, prosedur, alogaritma dan semacamnya.

Tiga ciri utama belajar menemukan yaitu: (1) mengeksplorasi dan memecahkan masalah untuk menciptakan, menggabungkan dan menggeneralisasi pengetahuan, (2) berpusat pada siswa, (3) kegiatan untuk menggabungkan pengetahuan baru dan pengetahuan yang sudah ada.

\section{Langkah-langkah Pembelajaran Discovery Learning}

Langkah-langkah pembelajaran discovery learning adalah sebagai berikut:

a. Identifikasi kebutuhan siswa, seleksi pendahuluan terhadap prinsip-prinsip, pengertian konsep dan generalisasi pengetahuan.

b. Seleksi bahan, problema/tugas-tugas, membantu dan memperjelas tugas/problema yang dihadapi siswa serta peranan masing-masing siswa. Mempersiapkan kelas dan alat-alat yang diperlukan,

c. Mengecek pemahaman siswa terhadap masalah yang akan dipecahkan,

d. Memberi kesempatan pada siswa untuk melakukan penemuan,

e. Membantu siswa dengan informasi/data jika diperlukan oleh siswa,

f. Memimpin analisis sendiri (self analysis) dengan pertanyaan yang mengarahkan dan mengidentifikasi masalah,

g. Merangsang terjadinya interaksi antara siswa dengan siswa,

h. Membantu siswa merumuskan prinsip dan generalisasi hasil penemuannya.

\section{Keuntungan Model Pembelajaran Discovery Learning.}

Beberapa keuntungan model pembelajaran discovery yaitu: (1) pengetahuan bertahan lama dan mudah diingat, (2) hasil belajar discovery learning mempunyai efek transfer yang lebih baik dari pada hasil lainnya, (3) secara menyeluruh belajar discovery learning meningkatkan penalaran siswa dan kemampuan untuk berpikir bebas. Secara khusus belajar penemuan melatih keterampilan-keterampilan kognitif siswa untuk menemukan dan memecahkan masalah tanpa pertolongan orang lain.

\section{Keunggulan Model Pembelajaran Discovery Laerning.}

Beberapa keunggulan model pembelajaran discovery juga diungkapkan oleh Suherman, dkk (2001: 179) sebagai berikut:

a. Siswa aktif dalam kegiatan belajar, sebab ia berpikir dan menggunakan kemampuan untuk menemukan hasil akhir, 
b. Siswa memahami benar bahan pelajaran, sebab mengalami sendiri proses menemukannya. Sesuatu yang diperoleh dengan cara ini lebih lama diingat,

c. Siswa yang memperoleh pengetahuan dengan model pembelajaran discovery akan lebih mampu mentransfer pengetahuannya ke berbagai konteks,

d. Model ini melatih siswa untuk lebih banyak belajar sendiri.

\section{Kelemahan Model Pembelajaran Discovery Learning.}

Selain memiliki beberapa keuntungan, model pembelajaran discovery learning juga memiliki beberapa kelemahan, diantaranya membutuhkan waktu belajar yang lebih lama dibandingkan dengan belajar menerima. Untuk mengurangi kelemahan tersebut maka diperlukan bantuan guru. Bantuan guru dapat dimulai dengan mengajukan beberapa pertanyaan dan dengan memberikan informasi secara singkat. Pertanyaan dan informasi tersebut dapat dimuat dalam Lembar Kerja Siswa (LKS) yang telah dipersiapkan oleh guru sebelum pembelajaran dimulai.

Model pembelajaran discovery learning yang mungkin dilaksanakan pada siswa SMA adalah metode penemuan terbimbing. Hal ini dikarenakan siswa SMA masih memerlukan bantuan guru sebelum menjadi penemu murni. Oleh sebab itu, model pembelajaran discovery learning yang akan digunakan dalam penelitian ini adalah model pembelajaran discovery learning terbimbing. Menemukan sendiri menimbulkan rasa puas. Kepuasan batin ini mendorong ingin melakukan penemuan lagi sehingga minat belajarnya meningkat,

\section{METODEPENELITIAN}

Penelitian Tindakan Kelas dilaksanakan pada kelas X IPS 1 SMA Negeri 8 Pekanbaru tahun pelajaran 2016/2017 pada mata ekonomi materi jurnal penyesuaian dan kertas kerja dengan jumlah siswa 35 orang terdiri dari 15 orang laki-laki dan 20 orang perempuan, kelas yang menjadi subjek adalah kelas heterogen yaitu yang memiliki latar belakang status sosial yang berbeda, tempat tinggal, hasil belajarnya dan prestasinya siswa bervariasi, mulai dari yang berkemampuan rendah, sedang, hingga kemampuan tinggi. Dalam hal ini masalah yang diangkat adalah meningkatkan hasil belajar siswa dengan menggunakan model pembelajaran discovery.

\section{Teknik Pengumpulan Data}

a) Tes Tertulis yang Berbentuk Tes Uraian

Dalam mengumpulkan data tentang hasil kemampuan pemecahan masalah Ekonomi pada pembahasan jurnal penyesuaian dan kertas kerja, maka peneliti membuat tes tertulis dan jawabannya.

b) Teknik Observasi/Pengamatan, untuk mengamati aktifitas siswa dan guru selama proses pembelajaran berlangsung.

\section{Teknik analisis data}

Teknik yang digunakan dalam menganalisis data adalah dengan menggunakan penyekoran. Menurut (Suharsimi Arikunto, 2009) penyekoran dilakukan dengan berdasarkan pada ketuntasan belajar siswa, jika hasil penyekoran telah mecapai batas nilai standar yang ditetapkan untuk mata pelajaran tertentu, maka siswa dinyatakan telah menguasai kompetensi yang ditentukan. Analisis data dilakukan untuk menguji hipotesis tindakan yang dilakukan secara bertahap dan berkesinambungan pada setiap akhir siklus. Data diolah dengan menggunakan presentase berdasarkan indikator keberhasilan siswa yang telah ditetapkan berdasarkan analisis data pada setiap akhir siklus ini penelitian dapat mengetahui sejauhmana peningkatan hasil belajar siswa pada mata pelajaran ekonomi.

\section{HASIL PENELITIAN}

Penelitian ini merupakan penelitian tindakan kelas yang menyajikan materi jurnal penyesuaian melalui model pembelajaran discovery yang diajarkan kepada 35 orang siswa 
kelas XII IPA 2 SMAN 8 Pekanbaru, sebanyak 2 siklus yaitu siklus I dan siklus II. Pelaksanaan siklus I dilakukan sebanyak 4 kali pertemuan dengan alokasi waktu 2 jam pelajaran (2 x 40 menit) untuk satu kali pertemuan.

Siklus II dilaksanakan sebnayak 2 kali pertemuan dengan alokasi waktu 2 jam pelajaran ( 2 x 40). Siklus II ini dilaksanakan karena hasil yang diperoleh dari pembelajaran pada siklus I belum memenuhi kriteria ketuntasan secara klasikal.

Pelaksanaan kegiatan pembelajaran mengacu pada rencana pelaksanaan pembelajaran (RPP) yang telah direncanakan. Selama proses kegiatan pembelajaran berlangsung siswa dibagai dalam beberapa kelompok, anggota kelompok terdiri dari 3-5 orang siswa secara heterogen.

Penelitian tindakan kelas menggunakan model pembelajaran discovery dengan tujuan meningkatkan hasil belajar siswa pada materi Neraca Pembayaran, dalam hal ini siswa diminta mengerjakan LKS secara berkelompok dan mengerjakan soal yang diberikan, siswa saling memberikan pemahaman kepada teman kelompoknya yang belum memahami. Setelah itu hasil diskusi masing-masing kelompok dipresentasikan.

Hasil evaluasi yang dilakukan pada akhir siklus I menunjukan bahwa dari 35 orang siswa yang dikenai tindakan, sebanyak 26 orang siswa tuntas dengan persentase $74,28 \%$, dan rata-rata kelas yaitu 71,43 . Siswa yang belum tuntas dan berada pada kategori kurang dan baik dengan jumlah siswa 9 orang siswa $25,71 \%$, dari 9 siswa yang berada dikategori kuarng baik dan baik yang berada pada kategori kurang sekali dengan jumlah siswa 6 orang siswa $17,14 \%$, hasil ini menunjukan bahwa nilai yang diperoleh siswa masih rendah dibandingkan kriteria ketuntasan yang telah ditetapkan. Rendahnya capaian pada siklus ini disebabkan dari berbagai faktor yang belum optimal yang diterapkan oleh guru seperti siswa belum terbiasa dengan model pembelajaran yang digunakan ataupun respon siswa dalam menerima pelajaran yang disampaikan. Hal ini dapat dilihat dari hasil pengamatan kegiatan guru ada 12 aspek yang diamati, terdapat 2 aspek $(16,67 \%)$ kriteria baik sekali, 7 aspek $(58,33 \%)$ kriteria baik, dan 3 aspek (25\%) cukup. Sedangkan aktivitas siswa dari 8 aspek yang dinilai terdapat 1 aspek (12,5\%) kriteri baik sekali, 4 aspek (50\%) baik, 3 aspek (37,5\%) cukup. Berbagai kekurangan yang terdapat pada siklus I selanjutnya disempurnakan pada siklus II, pada hasil pengamatan siklus II menunjukan bahwa dari pengamatan kegiatan guru dari 12 aspek yang diamati, 6 aspek (50\%) baik sekali, 5 aspek $(41,67 \%)$ baik, dan 1 aspek $(8,33 \%)$ dengan kriteria cukup, selanjutnya aktivitas siswa dari 8 aspek yang diamati terdapat 3 aspek $(37,5 \%)$ baik sekali, 4 aspek (50\%) baik, dan 1 aspek (12,5\%) dengan kriteria cukup, berdasarkan hasil evaluasi siklus II yang dilakukan akhir pelajaran menunjukan bahwa dari 35 orang siswa yang dikenakan tindakan tuntas sebanyak 34 orang siswa dari 35 orang siswa dengan ketuntasan klasikal yaitu 97,14\%, dengan rata-rata hasil belajar siswa yaitu 84,86. Dari siklus I mengalami kenaikan ke siklus II yaitu pada siklus II hanya 1 orang siswa yang belum tuntas dan tidak ada siswa pada kategori kurang seklai. Pada siklus II kelas sudah tuntas karena ketuntasan siswa telah mencapai 97,14\%.

Berdasarkan data tersebut menunjukan bahwa terdapat peningkatan hasil belajar siswa, sehingga hipotesis yang berbunyi: Jika digunakan model pembelajaran discovery Learning pada materi jurnal penyesuaian dan kerts kerja pada mata pelajaran ekonomi di SMA Negeri 8 Pekanbaru maka hasil belajar siswa akan meningkat dinyatakan dapat diterima.

\section{KESIMPULAN}

Berdasarkan hasil penelitian dan pembahasan, maka dapat dikemukakan simpulan bahwa hipotesis yang berbunyi, Jika diterapkan model pembelajaran discovery maka hasil belajar siswa pada mata pelajaran Ekonomi kelas XII IPA 2 SMAN 8 Pekanbaru, akan meningkat dan dapat diterima karena didukung dengan hasil analisis data: Pada siklus I hasil 
belajar siswa yang tuntas dalam proses pembelajaran ekonomi pada materi jurnal penyesuaian dan kertas kerja berjumlah 26 siswa dengan persentase 74,28\%, dan rata-rata kelas yaitu 71,43 . Siswa yang belum tuntas dan berada pada kategori kurang dan baik dengan jumlah siswa 9 orang siswa $25,71 \%$, dari 9 siswa yang berada dikategori kuarng baik dan baik yang berada pada kategori kurang sekali dengan jumlah siswa 6 orang siswa 17,14\%. Sedangkan pada siklus II, dari 35 orang siswa yang dikenakan tindakan tuntas sebanyak 34 orang siswa dengan presentase yaitu 97,14\%, dengan rata-rata hasil belajar siswa yaitu 84,86. Dari siklus I mengalami kenaikan ke siklus II yaitu pada siklus II hanya 1 orang siswa yang belum tuntas dan tidak ada siswa pada kategori kurang seklai. Pada siklus II kelas sudah tuntas karena ketuntasan siswa telah mencapai 97,14\%. Dengan demikian, ini menunjukan bahwa adanya peningkatan.

\section{SARAN}

Berdasarkan hasil penelitian dan kesimpulan di atas maka peneliti menyarankan sebagai berikut:

1. Model pembelajan discovery yang merupakan salah satu model pembelajaran yang dapat digunakan untuk meningkatkan hasil belajar siswa pada pembelajaran ekonomi.

2. Guru diharapkan mampu menerapkan model pembelajaran yang digunakan sesuai dengan langkah-langkah yang semestinya sehingga kesuksesan belajar siswa dapat tercapai.

\section{DAFTAR PUSTAKA}

Arifin. Zainal 2009. Evaluasi pembelajaran. Bangdung: PT Remaja Rosdakarya

Ahmad, Siregar. 2011. Pengaruh Model Pembelajaran Discovery Terhadap Hasil Belajar Siswa Standar Kompetensi Menguasai Teori Dasar Elektronika di SMK Teknik YPS Bandung Bandar Setia. Bandung.

Dimyati, Mudjiono. 2009. Belajar dan Pembelajaran. Jakarta: PT Rineka Cipta.

Djamara, Syaiful Bahri dan Aswan Zain. 2002. Strategi Belajar Mengajar.Jakarta: Rineka Cipta.

Gatot Sarjono, Simangunsong. 2008. Perbedaan Hasil Belajar Menggunakan Alat Ukur Listrik dan Elektronika Antara Siswa Yang Diajarkan Dengan Model Pembelajaran Discovery Dan Model Pembelajaran Konvensional Pada Siswa Kelas 1 SMK Swasta Teladan Medan. Kota Medan

Hamalik, Omar. 2001. Proses Belajar Mengajar. Bandung: Bumi Aksara

Jaya Sandana, Raja. 2009. Pengaruh Model Pembelajaran Discovery Dan Minat Kejuruan Terhadap Hasil Belajar MKDLE Pada Siswa Tingkat X Program Keahlian Teknik Pemanfaatan Tenaga Listrik SMK Negeri 5 Medan. Medan.

Mahmud, 2010. Psikologi Pendidikan. Bandung: CV Pustaka Setia

Pisenius, Telaumbanua. 2010. Perbedaan Hasil Belajar Menggunakan Alat/Instrument Bantu Untuk Pengukuran/Pengujian Antara Siswa Yang Diajarkan Dengan Model Pembelajaran Discovery Pada Siswa Kelas X SMK Negeri 2 Gunung Sitoli.

Purwanto, Ngalim. 1991. Administrasi Pendidikan. Jakarta: Mutiara

Slameto. 2010, Belajar Dan Faktor-Faktor Yang Mempengaruhinya. Jakarta:PT Rineka Cipta

Sudjana, Nana. 2006. Penilaian Hasil Proses Belajar Mengajar. Bandung:PT. Temaja Rosda karyana.

Suprijono, Agus. 2009. Cooperative Learning. Yogyakarta: Pustaka Pelajar 
Yamin, $\quad$ Martinis. 2008. Desain Pembelajaran Berbasis Tingkat Satuan Pendidikan. Jakarta: Gaung Persada Press Jakarta 